\title{
ANALYSIS OF MARKET TIMING TOWARD LEVERAGE OF NON-FINANCIAL COMPANIES IN INDONESIA
}

\author{
Vera Pipin Wulandari \\ Faculty of Economics and Business \\ Universitas Gadjah Mada \\ (verapipinwulandari@gmail.com) \\ Kusdhianto Setiawan \\ Faculty of Economics and Business, \\ Universitas Gadjah Mada \\ (s.kusdhianto@ugm.ac.id)
}

\begin{abstract}
This study aimed to examine the effect of market timing on leverage on non-financial companies in Indonesia. Market timing was tested on the hot and cold market conditions. Hot and cold markets are determined by the monthly market to book ratio. A hot (cold) market occurs when the average market to book ratio of a particular month is above (below) the value of the moving average of the monthly market to book ratio. This study also aimed to test whether non-financial companies in Indonesia persistently applied leverage policies. This study used two research models. The first model was a panel data with a sample size of 77 non-financial companies listed on the Indonesian Stock Exchange from 2002-2013.The second model was a cross section data with a sample size of 157 non-financial companies that conducted their IPO in Indonesia from 2003-2013. The dependent variable in both the research models was leverage ${ }_{t}\left(\right.$ lev $\left._{t}\right)$. The independent variables were market $t_{t}$ and leverage $t_{t-1}\left(l_{\text {ev }}{ }_{t-1}\right)$. The control variables were profitability $_{t-1}\left(\right.$ prof $\left._{t-1}\right)$; and size $t_{t-1}$. The results of this study indicated that market timing affected the leverage of non-financial companies listed on the Indonesian Stock Exchange. However, market timing did not affect the leverage of non-financial companies that had their IPO in Indonesia. The non-financial companies in Indonesia were not persistently applying a leverage policy. The capital structure of non-financial companies in Indonesia changed because of the influence of variable profitability and size (which supports the pecking order and trade off theory).
\end{abstract}

Keywords: market timing theory, leverage, hot and cold market, market to book ratio

\section{INTRODUCTION}

The goal of financial decision making is to maximize the shareholders' wealth. Such financial decisions include (1) the investment decision; (2) financing decision; and (3) dividend policy.

The most important funding decision is the value of the company's capital structure. The optimal capital structure by Brealey, et al (2011) would be a capital structure that could minimize the overall costs of capital or the average costs of capital in order to maximize its value.
There are several theories regarding the capital structure, which are the trade off theory, pecking order theory and market timing theory. Baker and Wurgler (2002) explained that equity market timing was an important aspect of corporate financing policy. The market timing theory says that companies tend to issue their shares when their market value is high and are likely to buy back the stock, or issue the debt, when the market value is low, in order to obtain funds at a cheaper cost of capital.

Barker and Wurgler (2002) explained that market timing negatively affected the level of 
leverage. That effect is permanent and had persistence in the capital structure for at least a ten year period. In the long run, the changes in capital structure are influenced by the opportunity to issue or buy back shares. This means that changes in the capital structure in the long term are influenced by the perceptions of managers in taking advantage of the issuance and repurchase of equity. So, the accumulation of capital structure is the result of a decision to utilize, by trading in the market, the value of the shares when they are overvalued or undervalued.

However, the research of Hovakimian (2006) explained that the effect of market timing on capital structures was temporary. That effect was negative and significant to the leverage only in the first year after the IPO. Hovakimian (2006) treated convertible debt as debt. But, Baker and Wurgler (2002) treated convertible debt as equity. This would reduce the leverage ratio.

Alti (2006) examined the effect of market timing on capital structures by using other variables, which happened to be the same as those used by Baker and Wurgler (2002). The difference was that Alti (2006) used a hot and/or cold market as a proxy of market timing. The research result showed that the hot market had a very strong negative effect on leverage, but the negative effect was quickly turned around. In the second year after the IPO, that effect was already lost. Overall, the results of this study showed that market timing was an important factor in financing activities in the short term, but the effects of market timing were limited in the long term.

One of the practices of market timing is utilizing the company's stock mispricing in the market, to obtain funds at relatively low capital costs. Mispricing is a condition in which the price of a stock, instead of being at its fair, realistic value is actually overvalued or undervalued on the market. The implication is that (1) if the stock is overvalued compared to its assessed fair value, the company will tend to issue new shares; and (2) if the stock is undervalued, the company would issue the debt and buy back its shares.
The consistent utilization of share mispricing can only occur in an inefficient market. In such inefficient markets, managers can choose the right time to issue shares, in other words when the price is above the fair value. Quoted from Saad and Siagian (2011), "The behavior of investors as if rational and arbitration mechanisms that not perfect will lead mispricing and cause markets to be inefficient". Empirical evidence has shown that the Indonesian capital market is in an inefficient condition (Kim and Shamsuddin, 2008; Hoque, et al, 2007). It gave signs that investors in Indonesia's capital market behaved as if they were rational. Therefore, it can be concluded that the theory of capital structure equity market timing by Baker and Wurgler (2002) should be applied to markets which are not efficient.

Quoted from Muhsinin (2011) "The research that has been conducted into the condition of the capital markets in Indonesia showed that the majority of shares had a low autocorrelation coefficient which was not significantly different from zero" (Husnan, 1990 and Esti, 1995). However, the Indonesian capital market cannot be said to be efficient because there were shares that had different autocorrelation coefficients to zero. The test was a weak form of efficiency testing. In testing the weak forms of efficiency, the capital market should be efficient if the changes in stock prices followed a random walk pattern. Therefore, investors cannot earn abnormal returns by using trading rules which were based on the information of a stock's previous price (Husnan, 2005). The change in the share's price in the past is expressed as a percentage. To determine the relationship between the past share price with the future share price, an autocorrelation coefficient is used. If the coefficient is found to be equal to zero then the capital market is efficient. This is because the pattern of changes in the share prices follows a random walk pattern.

The inefficient capital market condition raised the presumption that companies in Indonesia used the market timing theory to determine corporate funding. Therefore, the researchers wanted to examine the effect of market timing when tested on the hot and cold market condi- 
tions on the capital structure of non-financial companies in Indonesia in the two models. The first model examined the effect of market conditions (hot and cold markets) on the capital structure of non-financial companies listed on the Indonesian Stock Exchange (IDX) from 2002 to 2013. The second model examined the effect of market conditions (hot and cold markets) on the non-financial corporate capital structure which conducted an IPO in Indonesia from 2003 to 2013. The researchers used data from 2002 to 2013 as the period of study in order to reduce any bias in the result. The researchers also used non-financial companies as the sample because non-financial companies have different characteristics to financial companies. The financial companies tend to carry larger levels of debt than the non-financial companies for the same equivalent level of risk (Jensen and Meckling, 1976).

Hot and cold market values were determined based on the monthly market to book ratio. Hot (cold) market was the monthly average market to book ratio that was above (below) the monthly moving average market to book ratio. Market conditions were used as independent variables to test their effects on changes in the level of leverage used by the company.

The researchers focused on the market to book ratio to capture any market timing and its impact on the capital structure. There is one version of market timing where economic agents have motives that can be perceived as mispricing, which causes irrational mispricing of stocks from time to time. Based on this, a manager acting in the interest of his existing shareholders will take advantage of market timing in order to obtain funds at a lower capital cost by issuing shares which are overvalued at the time. The market to book ratio can be used to see if the value of the equity was overvalued or undervalued. Thus, the market to book ratio indicates the motivation for the market timing for the funding policy (Baker and Wurgler, 2002).

In this study, the researchers tried to investigate the persistence of non-financial corporate leverage policy in Indonesia. If such a policy of leverage by non-financial companies listed on the stock exchange was persistent, then the value of the leverage ratio in year $\mathrm{t}-1$ would be equal or nearly equal to the value of leverage in year $t$ (at any market condition in year $\mathrm{t}-1$ and $\mathrm{t}$ ).

Therefore, there were three objectives of the research. The first objective was to determine whether market conditions (hot and cold markets) affected the leverage of non-financial companies listed on the Indonesian Stock Exchange and of non-financial companies that held their IPO in Indonesia. The second objective was to determine whether non-financial companies listed on the Indonesian Stock Exchange and the non-financial companies who held their IPO in Indonesia persistently applied a leverage policy. The third objective was to determine whether the pecking order and trade off theory had any effect on the leverage of non-financial companies listed on the Indonesian Stock Exchange and non-financial companies that issued their IPO in Indonesia.

\section{THEORIES AND HYPOTHESES}

\section{Theory of Equity Market Timing}

The equity market timing theory (Baker and Wurgler, 2002) states that firms will tend to issue equity (decrease leverage) when they have a high market value and will buy back the equity or issue the debt when they have a low market value.

There exists two versions of market timing (Baker and Wurgler, 2002) based on two economic motive agents. The first version is that the economic agent has perceived a mispricing motif that is irrational. That causes mispricing in the share price of the companies from time to time. Therefore, managers that act in the interests of the shareholders will take advantage of this market timing in order to obtain funds at a lower capital cost by issuing shares when the price is overvalued. This applies to companies prior to and after their Initial Public Offering (IPO).

In the present study, the researchers tested the market timing for the hot and cold market conditions. Hot and cold markets are defined on the basis of the monthly market to book ratio. The hot (cold) market is a condition which is 
found when the average market to book ratio for a certain month is above (below) the moving average market to book ratio of that same month. The theory of market timing, as explained above, will be tested on hot and cold market conditions.

$\mathrm{H}_{1}$ : market condition (hot market and cold market) negatively affect the leverage changes in non-financial companies listed on the Indonesian Stock Exchange.

$\mathrm{H}_{5}$ : market conditions (hot market and cold market) negatively affect the leverage changes in non-financial companies that did their IPO in Indonesia.

\section{Persistence of Leverage Policy}

Leverage policy persistency is applied if the value of the leverage at $\mathrm{t}-1$ is equal or nearly equal to the value of the leverage at $t$, despite market conditions at the time $\mathrm{t}-1$ being the same or different to the market conditions at the time t. In the first model, if the leverage policy of non-financial listed companies on the stock exchange is persistent, the value of the leverage ratio in year t-1 will be equal or nearly equal to the value of the leverage in year $t$ (any market conditions in year t-1 and t). In the second mod$\mathrm{el}$, if the leverage policy of the non-financial corporations that held their IPOs in Indonesia is persistent, the value of the leverage ratio in year t-1 (the year prior to the IPO) will be equal or nearly equal to the value of leverage in year $t$ (the year after an IPO) for any market conditions in the years before and after the IPO. The hypotheses of persistence of leverage policy are formulated below:

$\mathrm{H}_{2}$ : non-financial companies listed on the Indonesian Stock Exchange persistently apply a leverage policy.

$\mathrm{H}_{6}$ : non-financial companies that had their IPO in Indonesia persistently apply a leverage policy.

The leverage policy of non-financial companies in Indonesia is persistent, if:

1) The control variable $\operatorname{Lev}_{t-1}$ has $t_{\text {value }}>t_{\text {table }}$; $p_{\text {value }}<\alpha(0.05)$.

2) The coefficient $\operatorname{Lev}_{t-1}$ is equal to or close to \pm 1. Where $t_{\text {value }}$ for $\operatorname{Lev}_{\mathrm{t}-1}$ variable is

$$
\begin{aligned}
& t_{\mathrm{value}}=\frac{\text { coefficient } \mathrm{lev}_{t-1}-1}{\text { standard error }} \\
& =\frac{\beta_{2}-1}{\text { standard error }}
\end{aligned}
$$

\section{Pecking Order Theory}

The profitability of a company is an important factor in determining its capital structure. If it has large retained earnings, the company will tend to use these retained earnings as working capital. This is because of the cost of information asymmetry. Issuance of debt has a cost asymmetry higher than that of the use of retained earnings in the fulfillment of its financing needs (Hanafi, 2008). Based on the theory of the pecking order as explained above, the following hypotheses were formulated:

$\mathrm{H}_{3}$ : profitability $_{\mathrm{t}-1}$ affects leverage ${ }_{t}$ in non-financial companies listed on the Indonesian Stock Exchange.

$\mathrm{H}_{7}$ : profitability $_{\mathrm{t}-1}$ affects leverage ${ }_{t}$ in non-financial companies that held their IPO in Indonesia.

\section{Trade Off Theory}

The trade off theory states that the use of debt in financing capital structures will increase the value of the company up to a certain optimum point. However, the use of debt after exceeding that optimum point will decrease the value of the company. This is because the benefits gained from the use of debt are no longer proportional to the increase in expenses related to the financial distress and agency conflict. The larger companies tend to have greater credibility. The larger companies can reduce their agency costs because they have clear control over the disipline of their managers in fulfilling their obligations to the lenders or shareholders. Posed benefits of decreased costs of this agency to make the size of the larger companies will increase the company's issuance of new debt (Brealey, et al, 2011). Based on the theory of trade off as explained above, the hypotheses are formulated: 
$\mathrm{H}_{4}$ : size $_{\mathrm{t}-1}$ affects leverage ${ }_{t}$ in non-financial companies listed on the Indonesian Stock Exchange.

$\mathrm{H}_{8}$ : size $_{\mathrm{t}-1}$ affects leverage $_{t}$ in non-financial companies that had an IPO in Indonesia.

\section{RESEARCH METHODOLOGY}

\section{Types and Sources of Data}

The data used in this study was secondary data. The secondary data comprised of the annual basic financial statements issued by the companies to the public. These were obtained from the Indonesian Stock Exchange; OSIRIS; and the Indonesian Capital Market Directory.

\section{Population and Sample}

The populations in this research comprised of non-financial companies listed on the Indonesian Stock Exchange between 2002-2013 (the first model) and non-financial companies that held their IPOs in Indonesia between 2003-2013 (the second model). The researchers used a purposive sampling technique to obtain a representative sample in accordance with the criteria, as set by the author. This purposive sampling method is a method of sampling research by matching certain criteria with the needs of the research (Sekaran, 2010). The author included specific considerations (judgment sampling) in order to provide the desired information. The criteria that were set by the author to determine the sample of the companies in the first research model were:

1) The non-financial companies that were listed on the Indonesian Stock Exchange during the period from 2002-2013.

2) These companies did not stop their operations and delist during the research period.

3) The companies provided annual financial reports periodically to the Indonesian Stock Exchange during the research period.

4) The companies had a complete data set that could be used in the research.

5) Based on the criteria above, the researcher found 77 samples for the first model.
The criteria that were set by the researcher to determine the sample of the companies in the second research model were:

1) The non-financial companies that held their Initial Public Offering (IPO) on the Indonesian Stock Exchange between 2003-2013.

2) The companies did not stop their operations and delist during the research period.

3) The companies provided annual financial reports periodically to the Indonesian Stock Exchange during the research period.

4) The companies had a complete data set that could be used in the research.

Based on the criteria above, the researcher obtained 157 samples for the first model.

\section{Models Analysis}

a. The First Model

$$
\begin{aligned}
\operatorname{Lev}_{\mathrm{i}, \mathrm{t}}= & \beta_{0}+\beta_{1}\left(\text { market }_{\mathrm{t}}+\beta_{2}\left(\operatorname{Lev}_{\mathrm{t}-1}\right)_{\mathrm{i}, \mathrm{t}}+\right. \\
& \beta_{3}\left(\operatorname{Prof}_{\mathrm{t}-1}\right)_{\mathrm{i}, \mathrm{t}}+\beta_{4}\left(\operatorname{Size}_{\mathrm{t}-1}\right)_{\mathrm{i}, \mathrm{t}}+\varepsilon_{\mathrm{i}, \mathrm{t}}
\end{aligned}
$$

where:

$\operatorname{Lev}_{\mathrm{i}, \mathrm{t}}=$ leverage on firm $\mathrm{i}$ in year $\mathrm{t}$

$(\text { market })_{\mathrm{t}}=$ market conditions in year $\mathrm{t}$, described by a dummy variable, which is the number one (1) if the market condition in year $t$ is more than 50 percent of the monthly average market to book ratio in year $t$ above the monthly moving average market to book ratio in year t. Zero (0) if the market condition in year $t$ is more than 50 percent of the monthly average market to book ratio in year $\mathrm{t}$ below the monthly moving average market to book ratio in year $t$.

$\left(\operatorname{lev}_{\mathrm{t}-1}\right)_{\mathrm{i}, \mathrm{t}}=$ leverage $_{\mathrm{t}-1}$ firm $\mathrm{i}$ in year $\mathrm{t}$

$\left(\operatorname{Prof}_{\mathrm{t}-1}\right)_{\mathrm{i}, \mathrm{t}}=$ profitability $_{\mathrm{t}-1}$ firm $\mathrm{i}$ in year $\mathrm{t}$

$\left(\text { Size }_{t-1}\right)_{i, t}=$ size $_{t-1}$ firm $i$ in year $t$

b. The Second Model

$$
\begin{aligned}
\left(\operatorname{Lev}_{\mathrm{t}}\right)_{\mathrm{i}}= & \beta_{0}+\beta_{1}\left(\operatorname{Market}_{\mathrm{t}}\right)_{\mathrm{i}}+\beta_{2}\left(\operatorname{Lev}_{\mathrm{t}-1}\right)_{\mathrm{i}}+ \\
& \beta_{3}\left(\operatorname{Prof}_{\mathrm{t}-1}\right)_{\mathrm{i}}+\beta_{4}\left(\operatorname{Size}_{\mathrm{t}-1}\right)_{\mathrm{i}}+\varepsilon \mathrm{i}
\end{aligned}
$$

where:

$\left(\operatorname{Lev}_{\mathrm{t}}\right)_{\mathrm{i}},=$ leverage after the IPO shares in firm i 
$\left(\text { Market }_{\mathrm{t}}\right)_{\mathrm{i}}=$ the current market conditions to go public or do an IPO of shares in firm i, is described by a dummy variable, which is the number one (1) if the company i goes public during hot months of the market and the number zero (0) if firm i goes public during cold months of the market

$\left(\operatorname{Lev}_{\mathrm{t}-1}\right)_{\mathrm{i}}=$ leverage before the IPO shares (pre-IPO) in firm i

$\left(\text { Prof }_{\mathrm{t}-1}\right)_{\mathrm{i}}=$ profitability before the IPO shares (pre-IPO) in firm i

$\left(\text { Size }_{\mathrm{t}-1}\right)_{\mathrm{i}}=$ the size of the company before the IPO shares (pre-IPO).

\section{Measuring Research Variables}

a. Dependent Variables

Baker and Wurgler (2002) and Alti (2006) defined the level of leverage as the ratio of the book value of debt to the total assets as follows.

Lev $=$ Debts $/$ Assets

Debts represent the total debt that consists of long-term debt and short-term debt. Assets are the total asset of the company based on the book value.

b. Independent Variables

\section{- Market}

Market timing will be tested in hot market and cold market conditions. Hot and cold markets are defined on the basis of the monthly market to book ratio. A hot market is a market in a condition where the average market to book ratio during a certain month is above the moving average market to book ratio of that month. A cold market is when the average market to book ratio is below the moving average market to book ratio during a certain month.

In the first model, this variable was described by a dummy variable, which was the number one (1) if the market condition in year $\mathrm{t}$ was more than 50 percent of the monthly average market to book ratio in year $\mathrm{t}$ above the monthly moving average market to book ratio in year t. Zero (0) if the market condition in year $\mathrm{t}$ was more than 50 percent of the monthly average market to book ratio in year $\mathrm{t}$ below the monthly moving average market to book ratio in year $\mathrm{t}$.

In the second model, this variable was described by a dummy variable, which was the number one (1) if company $i$ went public during the hot months of the market and the number zero (0) if firm $\mathrm{i}$ went public during the cold months of the market.

- Leverage $e_{t-1}\left(\operatorname{Lev}_{\mathrm{t}-1}\right)$

Leverage $_{t-1}$ was calculated by dividing the total debt $t_{t-1}$ to total assets $\mathrm{t}_{-1}$.

Formulated as follows:

$\left(\operatorname{Lev}_{\mathrm{t}-1}\right)=\left(\operatorname{Debt}_{\mathrm{t}-1}\right) /\left(\right.$ Assets $\left._{\mathrm{t}-1}\right)$

Lev $_{\mathrm{t}-1}$ variable was used to test the persistency of the leverage policy.

c. Variable Control

- Profitability $\mathrm{t}_{\mathrm{t}-1}$

According to Titman and Wessels (1988) profitability is defined as the operating income divided by the total assets.

$\left(\operatorname{Prof}_{\mathrm{t}-1}\right)=\left(\mathrm{OI}_{\mathrm{t}-1}\right) /\left(\right.$ Assets $\left._{\mathrm{t}-1}\right)$

Prof $_{\mathrm{t}-1}$ was used to test the pecking order theory

- Size t-1 $_{1}$

According to Baker and Wurgler (2002) and Alti (2006) size is defined as the logarithm of net sales (net sales).

$$
\begin{aligned}
& \left(\text { Size }_{\mathrm{t}-1}\right)=\left(\text { logarithm net sales } \mathrm{t}_{\mathrm{t}-1}\right) \\
& =\left(\log \text { net sales } \mathrm{t}_{\mathrm{t}-1}\right)
\end{aligned}
$$

In this study, the inflation rate of net sales has been adjusted using the GDP deflator with a base year of 2000. Size was used to test the trade off theory.

\section{Determination of the Conditions of Hot and Cold Markets}

The steps for the determination of the conditions of hot and cold market were as follows. 
- Firstly, by seeking the average value of the monthly market to book ratio of non-financial companies listed on the Indonesian Stock Exchange from 2002-2013 (first sample model of 77 companies).

- Secondly, by seeking the value of the monthly moving average market to book ratio (with a size window of twelve months).

- Thirdly, by determining the monthly market conditions during the period from 2003-2013. Hot months occurred in the market when the average market to book ratio of a month was above the moving average market book ratio of a month and cold months were if the average market to book ratio of a month was below the moving average market value to book ratio of a month.

\section{RESULTS AND DISCUSSION}

\section{Analysis of Hot and Cold Markets}

Figure 1 below shows the conditions of hot and cold market (monthly) during the study.

In the first model, the independent variable was the market condition in year $\mathrm{t}\left(\right.$ market $\left._{\mathrm{t}}\right)$, described by a dummy variable. Number one (1) if it was more than 50 percent of the value of monthly average market to book ratio in year $t$ above the value of the monthly moving average market to book ratio in year t. Zero (0) if more than 50 percent of the value of monthly average market to book ratio in year $t$ was below the value of the monthly moving average market to book ratio in year $t$. Therefore, the market conditions of non-financial companies in Indonesia each year during the study period (2003-2013) can be seen in detail in the appendix, and are summarized in the table 1.

Based on Table 1, we can see the market conditions during our study period from 20032013. The cold markets occurred in 2003, 2005, 2006, 2008, 2011, 2012, and 2013, and hot markets occurred in 2004, 2007, 2009, and 2010.

In the second model, the independent variable was the current market conditions to go public or hold an IPO of shares in firm i $\left(\text { market }_{\mathrm{t}}\right)_{\mathrm{i}}$, which was also described by a dummy variable. Number one (1) if the company i went public when the market condition was a hot market and the number zero (0) if firm i went public when the market was a cold market. The table below shows the number of non-financial companies that went public or did an IPO during hot and cold market conditions.

Based on Table 2, we can see, that there were 74 non-financial companies that held their IPO during a hot market condition (from 20032013), and 83 non-financial companies which did their IPO while in a cold market condition (from 2003-2013).

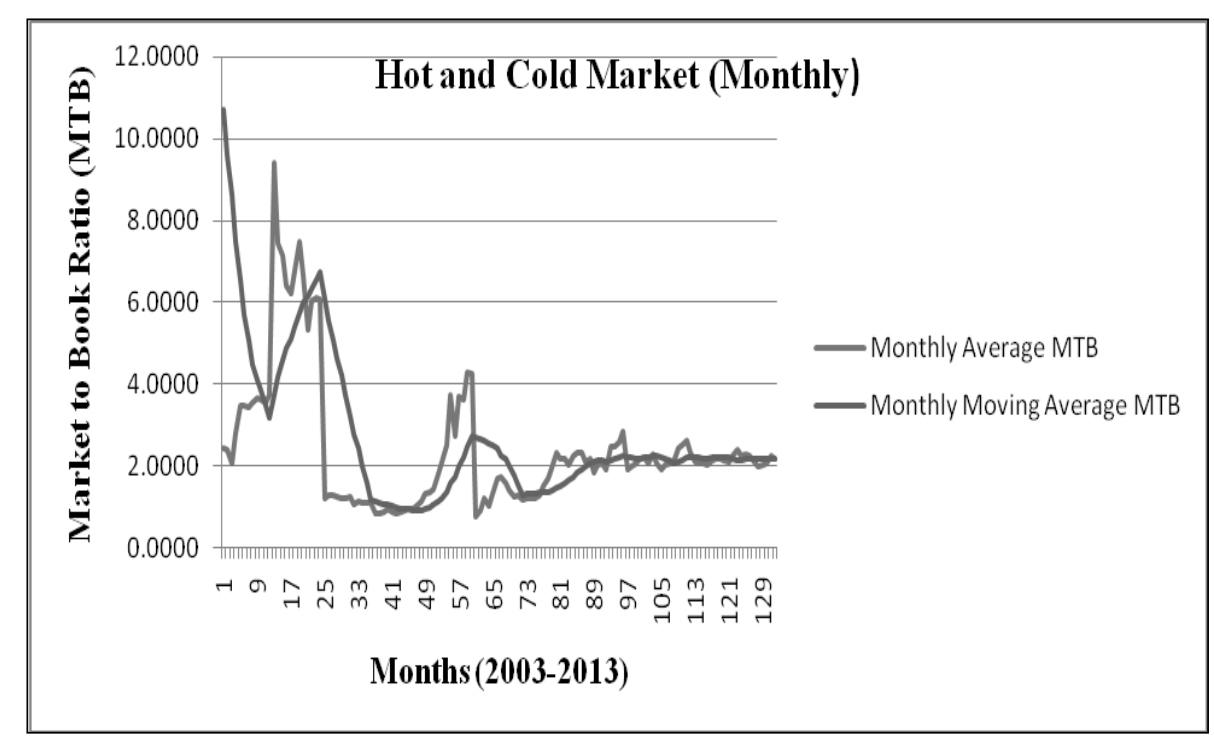

Figure 1. Tthe conditions of hot and cold market (monthly) 
Table 1. Market Condition during Study Period

\begin{tabular}{cc}
\hline Years & Market Conditions \\
\hline 2003 & Cold \\
2004 & Hot \\
2005 & Cold \\
2006 & Cold \\
2007 & Hot \\
2008 & Cold \\
2009 & Hot \\
2010 & Hot \\
2011 & Cold \\
2012 & Cold \\
2013 & Cold \\
\hline
\end{tabular}

Table 2. Number of Non-Financial Companies that did an IPO during Hot and Cold Market Conditions

\begin{tabular}{ccc}
\hline \multirow{2}{*}{ Years } & \multicolumn{2}{c}{$\begin{array}{c}\text { Number of Non-Financial Company that did an IPO during Hot and } \\
\text { Cold Market Conditions }\end{array}$} \\
\cline { 2 - 3 } & Hot Market & Cold Market \\
\hline 2003 & 1 & 2 \\
2004 & 5 & 2 \\
2005 & 0 & 4 \\
2006 & 3 & 6 \\
2007 & 18 & 0 \\
2008 & 0 & 15 \\
2009 & 9 & 2 \\
2010 & 14 & 7 \\
2011 & 9 & 15 \\
2012 & 3 & 17 \\
2013 & 12 & 13 \\
\hline Total & $\mathbf{7 4}$ & $\mathbf{8 3}$ \\
\hline
\end{tabular}

2. Analysis of The Research Results

The data from this research were processed using Eview 7.0. and Tables 3 and 4 show the results.

So, the equation of the first model (1) is :

$$
\begin{aligned}
\operatorname{Lev}_{i, t}= & 0,2243-0,0139(\text { market })_{t}+ \\
& 0,6929\left(\operatorname{Lev}_{t-1}\right)_{i, t}-0,333\left(\operatorname{Prof}_{t-1}\right)_{i, t}- \\
& 0,0023\left(\operatorname{Size}_{t-1}\right)_{i, t}+\varepsilon_{\mathrm{i}, \mathrm{t}}
\end{aligned}
$$

So, the equation of the second model (2) is :

$$
\begin{aligned}
\left(\operatorname{Lev}_{t}\right)_{i}= & -0,4739-0,0078\left(\text { market }_{t}\right)_{i}+ \\
& 0,4659\left(\operatorname{Lev}_{t-1}\right)_{i}-0,3193\left(\operatorname{Prof}_{t-1}\right)_{i}+ \\
& 0,0592\left(\operatorname{Size}_{t-1}\right)_{i}+\varepsilon_{\mathrm{t}}
\end{aligned}
$$

Based on the research results above, we can determine the significance of the hypothesis testing in Table 5. 
Table 3. The Results of the First Model (1)

\begin{tabular}{lcccc}
\hline \multicolumn{1}{c}{ Variable } & Coefficient & Std. Error & t-Statistic & Prob. \\
\hline Market & $-0,0139$ & 0,0048 & $-2,895$ & 0,0039 \\
Leverage $_{\mathrm{t}-1}$ & 0,6929 & 0,0242 & 28,676 & 0,0000 \\
Profitability $_{\mathrm{t}-1}$ & $-0,333$ & 0,0559 & $-5,9611$ & 0,0000 \\
Size $_{\mathrm{t}-1}$ & $-0,0023$ & 0,008 & $-0,2932$ & 0,7694 \\
$\mathrm{C}$ & 0,2243 & 0,091 & 2,4638 & 0,0140 \\
\hline R-squared & & 0,9059 & \\
\hline
\end{tabular}

Table 4. The Results of the Second Model (2)

\begin{tabular}{lcccc}
\hline \multicolumn{1}{c}{ Variable } & Coefficient & Std. Error & t-Statistic & Prob. \\
\hline Market & $-0,0078$ & 0,0259 & $-0,3009$ & 0,7639 \\
Leverage $_{\mathrm{t}-1}$ & 0,4659 & 0,09 & 5,1721 & 0,0000 \\
Profitability $_{\mathrm{t}-1}$ & $-0,3193$ & 0,144 & $-2,2171$ & 0,0281 \\
Size $_{\mathrm{t}-1}$ & 0,0592 & 0,0236 & 2,5052 & 0,0133 \\
$\mathrm{C}$ & $-0,4739$ & 0,2344 & $-2,0224$ & 0,0449 \\
\hline R-squared & \multicolumn{3}{c}{0,4029} \\
\hline
\end{tabular}

Source of the data in Tables 3 and 4: Indonesian Stock Exchange; OSIRIS; and the Indonesian Capital Market Directory 2002-2013 (the primary data were processed by using Eviews 7.0 in 2014).

Table 5. Research Results: The Effect of the Independent Variable on the Dependent Variable

\begin{tabular}{|c|c|c|}
\hline Var. Dependent & The First Model & The Second Model \\
\hline $\begin{array}{c}\text { Var. } \\
\text { Independent }\end{array}$ & $\begin{array}{l}\text { Leverage }_{t} \text { on non-financial companies } \\
\text { listed on the Stock Exchange }\end{array}$ & $\begin{array}{c}\text { Leverage }_{t} \text { on non-financial companies } \\
\text { that held IPOs in Indonesia }\end{array}$ \\
\hline $\begin{array}{l}\text { Market Conditions (hot } \\
\text { and cold market) }\end{array}$ & $\begin{array}{l}\text { Significant }(-) \\
\mathrm{t}_{\text {statistic }}=-2,895>\mathrm{t} \text { table }=-2,015 \text { and } \rho \\
\text { value market }=0,0039<\alpha=5 \%\left(\mathrm{H}_{1} \text { is }\right. \\
\text { supported }) .\end{array}$ & $\begin{array}{l}\text { Not Significant } \\
\mathrm{t}_{\text {statistic }}=-0,3009<\mathrm{t}_{\text {table }}=-2,015 \text { and } \rho \\
\text { value market }=0,7639>\alpha=5 \%\left(\mathrm{H}_{5} \text { is }\right. \\
\text { not supported }) .\end{array}$ \\
\hline $\begin{array}{l}\text { Persistence of Leverage } \\
\text { Policy }\end{array}$ & $\begin{array}{l}\text { Not Significant } \\
t_{\text {statistic }}=28,676>\mathrm{t}_{\text {table }}=2,015 \text { and } \rho \\
\text { value } \operatorname{lev}_{\mathrm{t}-1}=0,00<\alpha=5 \% \text {. But the } \\
\text { coefficient of lev } \mathrm{v}_{\mathrm{t}-1} \text { is not equal or close } \\
\text { to } 1\left(\mathrm{H}_{2} \text { is not supported }\right) \text {. }\end{array}$ & $\begin{array}{l}\text { Not Significant } \\
\mathrm{t}_{\text {statistic }}=5,1721>\mathrm{t} \text { table }=2,015 \text { and } \rho \\
\text { value } \operatorname{lev}_{\mathrm{t}-1}=0,0<\alpha=5 \% \text {. But the } \\
\text { coefficient of } \operatorname{lev}_{\mathrm{t}-1} \text { is not equal or close } \\
\text { to } 1\left(\mathrm{H}_{6} \text { is not supported). }\right.\end{array}$ \\
\hline $\operatorname{Prof}_{\mathrm{t}-1}$ & $\begin{array}{l}\text { Significant }(-) \\
\mathrm{t}_{\text {statistic }}=-5,9612>\mathrm{t}_{\text {table }}=-2,015 \text { and } \rho \\
\text { value } \text { prof }_{\mathrm{t}-1}=0,0000<\alpha=5 \%\left(\mathrm{H}_{3} \text { is }\right. \\
\text { supported }) .\end{array}$ & $\begin{array}{l}\text { Significant }(-) \\
\mathrm{t}_{\text {statistic }}=-2,2171>\mathrm{t} \text { table }=-2,015 \text { and } \rho \\
\text { value } \text { prof }_{\mathrm{t}-1}=0,0281<\alpha=5 \%\left(\mathrm{H}_{7} \text { is }\right. \\
\text { supported }) .\end{array}$ \\
\hline Size $_{t-1}$ & $\begin{array}{l}\text { Not Significant } \\
\mathrm{t}_{\text {statistic }}=-0,2932<\mathrm{t}_{\text {table }}=-2,015 \text { and } \rho \\
\text { value } \text { size }_{\mathrm{t}-1}=0,7694>\alpha=5 \%\left(\mathrm{H}_{4} \text { is not }\right. \\
\text { supported }) .\end{array}$ & $\begin{array}{l}\text { Significant }(+) \\
\mathrm{t}_{\text {statistic }}=2,5052>\mathrm{t} \text { table }=2,015 \text { and } \rho \\
\text { value market }=0,0133<\alpha=5 \%\left(\mathrm{H}_{8} \text { is }\right. \\
\text { supported }) .\end{array}$ \\
\hline
\end{tabular}

\section{Description:}

$\mathrm{t}$ in first model means in year $\mathrm{t}$

$\mathrm{t}$ in second model means the year after the IPO 
Economic agents have perceived mispricing motives as being irrational. It causes mispricing (share prices overvalued or undervalued) in shares of the companies from time to time. This is because the capital market in Indonesia is inefficient. Economic agents can earn abnormal returns by using irrelevant information. Nonfinancial corporate managers take advantage of mispricing in Indonesian markets to determine their funding structure. This can be seen in Table 3 above, the market conditions (hot and cold markets) have affected the leverage of the nonfinancial companies that were listed on the Indonesian Stock Exchange $\left(\mathrm{H}_{1}\right.$ is supported). The companies publishing the equity looked for whether the market was in a hot or cold condition (market timing occurred in Indonesia, especially in the non-financial companies that were listed on the Indonesian Stock Exchange). Financial managers utilized the mispricing of the stock to establish their optimal capital structure policy. The non-financial companies that were listed on the Indonesian Stock Exchange did not persistently apply a leverage policy $\left(\mathrm{H}_{2}\right.$ is not supported). Profitability $\mathrm{t}_{\mathrm{t}-1}$ had significant effects on leverage $_{t}$ on non-financial companies listed on the stock exchange $\left(\mathrm{H}_{3}\right.$ is supported). The relationship between profitability $\mathrm{t}_{-1}$ and leverage $\mathrm{t}_{\mathrm{t}}$ was negative. The companies that had great profitability tended to use internal sources of funding rather than external sources (such as debt) because the costs of information asymmetry on internal funding were lower than the costs of information asymmetry for external funding (this supports the pecking order theory). Size $\mathrm{t}_{\mathrm{t}-1}$ had no effect on the leverage $e_{t}$ of non-financial companies that were listed on the Indonesian Stock Exchange $\left(\mathrm{H}_{4}\right.$ is not supported). The size of the non-financial companies that were listed on the Indonesian Stock Exchange did not affect the leverage ratio in the following year. Therefore, the capital structure of the non-financial companies listed on the Indonesian Stock Exchange was influenced by market timing and profitability $_{\mathrm{t}-1}$.

Based on the regression result of the first model, $\mathrm{R}$-squared $\left(\mathrm{R}^{2}\right)$ was 0,9059 , which means the leverage ${ }_{t}$ of the non-financial companies that were listed on the Indonesian Stock Exchange could be explained by the model at 90,59 percent and the remainder of it could be explained by other variables outside of the model, at 9,41 percent.

Market conditions (hot and cold markets) had no effect on the leverage of the non-financial companies that did their IPOs in Indonesia $\left(\mathrm{H}_{5}\right.$ is not supported). Finance managers at the nonfinancial companies in Indonesia did not pay attention to the IPO market conditions (market timing did not occur in Indonesia, particularly in non-financial companies that did IPOs in Indonesia). The non-financial companies that did IPOs in Indonesia did not persistently apply leverage policies $\left(\mathrm{H}_{6}\right.$ is not supported). Corporate leverage policy changes were not affected by market conditions, but were influenced by the size and profitability of the company before the IPO. Profitability $y_{\mathrm{t}-1}$ had a significant effect on leverage $_{t}$ for the non-financial companies that did IPOs in Indonesia ( $\mathrm{H}_{7}$ is supported). The relationship between the two variables was negative. If the profitability of the company before an IPO was high, the leverage of the company after the IPO fell, because the manager chose an internal funding source for the profitability of the company, because that had a lower information asymmetry cost than issuing debt. If the profitability of the company before an IPO was low, the leverage of the company after its IPO would rise because internal capital resources were not sufficient to meet the financing needs of the company (which supports the pecking order theory).

Size $_{t-1}$ had a significant effect on leverage ${ }_{t}$ on the non-financial companies that did IPOs in Indonesia $\left(\mathrm{H}_{8}\right.$ is supported). The relationship between the two variables was positive. The large companies tended to have greater credibility and had clear control over their managers in fulfilling their obligations to the lenders or shareholders thus reducing agency costs. The benefit from the reduction of agency costs means the large size of the companies can increase their company's new debt issue. If the size of the nonfinancial companies in Indonesia prior to their IPO was large, then the leverage of the nonfinancial companies in Indonesia after their IPO would also be large. If the size of the non-financial companies in Indonesia prior to their IPO was small, then the leverage of such companies 
in Indonesia after the IPO would be small (supports the trade-off theory).

Based the on regression result of the second model, $\mathrm{R}$-squared $\left(\mathrm{R}^{2}\right)$ was 0,4029 . It means the leverage $_{t}$ of the non-financial companies that were listed on the Indonesian Stock Exchange could be explained by the model at 40,29 percent and the remainder of it could be explained by other variables outside of the model at 59,71 percent.

\section{CONCLUSION}

Based on the analysis of the results of the first model, it could be concluded that the market conditions (hot and cold markets) affected the leverage of the non-financial companies that were listed on the Indonesian Stock Exchange. However, based on the analysis of the result of the second model, it could be concluded that market conditions (hot and cold markets) did not affect the leverage of the non-financial companies that did their IPOs in Indonesia. This means that the non-financial firms in Indonesia issuing equity considered the market conditions (a hot or cold market). Yet, the non-financial firms in Indonesia which issued equity did not consider the market conditions (hot or cold market) when issuing equity the first time (IPO). In addition, the capital structure of the companies in Indonesia changed due to the influence of the variable size and profitability of the company.

The non-financial companies that were listed on the Indonesian Stock Exchange and the nonfinancial companies that did IPOs in Indonesia did not apply persistent leverage policies. This means that the leverage of the non-financial companies in Indonesia in year t-1 and the leverage of the non-financial companies before their IPO were not equal with the leverage of the nonfinancial companies in Indonesia in year $t$ and the leverage of the non-financial companies after their IPO. This could mean a change in the capital structure policy of the non-financial companies in Indonesia. The changes in capital structure policies were not only caused by the market conditions (hot and cold markets) when issuing equity, but also caused by the variable profitability and size of the companies.

\section{REFERENCES}

Alti, A. (2006) How Persistent Is The Impact of Market Timing on Capital Structure? Journal of Finance, 61 (4): 1681-1710

Barker, M. and Wurgler, J. (2002) Market Timing and Capital Structure. Journal of Finance, 57 (1): 1-32

Brealey, R.A., Myers, S.C., and Marcus, A. J. (2011). Principles of Corporate Finance 10/e. New York: McGraw-Hill

Gujarati, D. (2003) Basic Econometrics Fourth Edition. New York: McGraw-Hill

Hanafi, M.M. (2008) Manajemen Keuangan Edisi Pertama. Yogyakarta: BPFE

Muhsinin, N. (2011) Analisis Pengaruh Market Timing Terhadap Kebijakan Leverage Perusahaan. Skripsi Jurusan Manajemen Universitas Gadjah Mada

Hovakimian, A. (2006) Are Observed Capital Structures Determined by Equity Market Timing?. Journal of Financial and Quantitative Analyisis, 41 (1): 221-243

Jansen, M. and Meckling, W. (1976) Theory of the Firm: Managerial Behavior, Agency Costs and Ownership Structure. Journal of Financial Economics, 3 (4): 305-360

Kennedy. (2003) A Guide to Econometrics Fifth Edition. Blackwell Publishing Victoria

Saad, M. and Siagian, H. (2011) Sentimen Investor, Kendala Keuangan, dan Equity

Market Timing. Finance and Banking Journal, $13(1): 1-15$

Sartono, A. (2008). Manajemen Keuangan Teori dan Aplikasi Edisi Keempat. Yogyakarta: BPFE

Sekaran U., and Bougie R. (2010) Research Method for Business: A Skill Building Approach Fifth Edition. John Wiley and Sons

Titman, S. and R, Wessels. (1988) The Determinants of Capital Structure Choice. Journal of Finance, 43 (1): 1-19

Widarjono, A. (2009). Ekonometrika: Pengantar dan Aplikasinya. Yogyakarta: Penerbit Ekonisia 


\section{APPENDIX}

Market Condition during the Study Period

\begin{tabular}{|c|c|c|c|c|}
\hline \multirow[t]{2}{*}{ Months } & \multirow{2}{*}{$\begin{array}{c}\text { Moving Average } \\
\text { MTB } \\
\text { (Monthly) }\end{array}$} & \multirow{2}{*}{$\begin{array}{c}\text { Moving Average MTB (Monthly) } \\
\text { (Size Window = } 12 \text { Month) }\end{array}$} & \multirow{2}{*}{$\begin{array}{l}\text { Market Condition } \\
\text { (Monthly) }\end{array}$} & \multirow{2}{*}{$\begin{array}{c}\text { Market } \\
\text { Condition } \\
\text { In Year t }\end{array}$} \\
\hline & & & & \\
\hline Jan-03 & 2.4304 & 10.7148 & Cold Market & \multirow{12}{*}{ Cold Marke } \\
\hline Feb-03 & 2.4139 & 9.6141 & Cold Market & \\
\hline Mar-03 & 2.0747 & 8.6561 & Cold Market & \\
\hline Apr-03 & 2.7967 & 7.4895 & Cold Market & \\
\hline May-03 & 3.4622 & 6.5574 & Cold Market & \\
\hline Jun-03 & 3.4651 & 5.7197 & Cold Market & \\
\hline Jul-03 & 3.4442 & 5.0608 & Cold Market & \\
\hline Aug-03 & 3.5304 & 4.4977 & Cold Market & \\
\hline Sep-03 & 3.6518 & 4.1259 & Cold Market & \\
\hline Oct-03 & 3.6277 & 3.8452 & Cold Market & \\
\hline Nov-03 & 3.5477 & 3.4676 & Hot Market & \\
\hline Dec-03 & 3.7167 & 3.1801 & Hot Market & \\
\hline Jan-04 & 9.3961 & 3.7606 & Hot Market & \multirow{12}{*}{ Hot Market } \\
\hline Feb-04 & 7.4313 & 4.1787 & Hot Market & \\
\hline Mar-04 & 7.1296 & 4.6000 & Hot Market & \\
\hline Apr-04 & 6.4078 & 4.9009 & Hot Market & \\
\hline May-04 & 6.2123 & 5.1301 & Hot Market & \\
\hline Jun-04 & 6.7850 & 5.4067 & Hot Market & \\
\hline Jul-04 & 7.4790 & 5.7430 & Hot Market & \\
\hline Aug-04 & 6.6477 & 6.0027 & Hot Market & \\
\hline Sep-04 & 5.3168 & 6.1415 & Cold Market & \\
\hline Oct-04 & 6.0294 & 6.3416 & Cold Market & \\
\hline Nov-04 & 6.0993 & 6.5542 & Cold Market & \\
\hline Dec-04 & 6.0784 & 6.7511 & Cold Market & \\
\hline Jan-05 & 1.2148 & 6.0693 & Cold Market & \multirow{12}{*}{ Cold Market } \\
\hline Feb-05 & 1.2870 & 5.5573 & Cold Market & \\
\hline Mar-05 & 1.2960 & 5.0711 & Cold Market & \\
\hline Apr-05 & 1.2419 & 4.6406 & Cold Market & \\
\hline May-05 & 1.2060 & 4.2234 & Cold Market & \\
\hline Jun-05 & 1.2188 & 3.7596 & Cold Market & \\
\hline Jul-05 & 1.2435 & 3.2400 & Cold Market & \\
\hline Aug-05 & 1.0808 & 2.7761 & Cold Market & \\
\hline Sep-05 & 1.1540 & 2.4292 & Cold Market & \\
\hline Oct-05 & 1.1000 & 2.0184 & Cold Market & \\
\hline Nov-05 & 1.1220 & 1.6036 & Cold Market & \\
\hline Dec-05 & 1.0875 & 1.1877 & Cold Market & \\
\hline Jan-06 & 0.8463 & 1.1570 & Cold Market & \multirow{10}{*}{ Cold Market } \\
\hline Feb-06 & 0.8316 & 1.1190 & Cold Market & \\
\hline Mar-06 & 0.9003 & 1.0861 & Cold Market & \\
\hline Apr-06 & 0.9528 & 1.0620 & Cold Market & \\
\hline May-06 & 0.8912 & 1.0357 & Cold Market & \\
\hline Jun-06 & 0.8593 & 1.0058 & Cold Market & \\
\hline Jul-06 & 0.8891 & 0.9762 & Cold Market & \\
\hline Aug-06 & 0.9171 & 0.9626 & Cold Market & \\
\hline Sep-06 & 0.9427 & 0.9450 & Cold Market & \\
\hline Oct-06 & 0.9613 & 0.9334 & Hot Market & \\
\hline
\end{tabular}




\begin{tabular}{|c|c|c|c|c|}
\hline Nov-06 & 1.0289 & 0.9257 & Hot Market & \\
\hline Dec-06 & 1.1255 & 0.9288 & Hot Market & \\
\hline Jan-07 & 1.3170 & 0.9681 & Hot Market & \multirow{12}{*}{ Hot Market } \\
\hline Feb-07 & 1.3703 & 1.0130 & Hot Market & \\
\hline Mar-07 & 1.4372 & 1.0577 & Hot Market & \\
\hline Apr-07 & 1.8260 & 1.1305 & Hot Market & \\
\hline May-07 & 2.0882 & 1.2302 & Hot Market & \\
\hline Jun-07 & 2.4987 & 1.3668 & Hot Market & \\
\hline Jul-07 & 3.7438 & 1.6047 & Hot Market & \\
\hline Aug-07 & 2.7196 & 1.7549 & Hot Market & \\
\hline Sep-07 & 3.6867 & 1.9836 & Hot Market & \\
\hline Oct-07 & 3.6173 & 2.2049 & Hot Market & \\
\hline Nov-07 & 4.2837 & 2.4762 & Hot Market & \\
\hline Dec-07 & 4.2376 & 2.7355 & Hot Market & \\
\hline Jan-08 & 0.7718 & 2.6901 & Cold Market & \multirow{12}{*}{ Cold Market } \\
\hline Feb-08 & 0.9099 & 2.6517 & Cold Market & \\
\hline Mar-08 & 1.2097 & 2.6327 & Cold Market & \\
\hline Apr-08 & 1.0349 & 2.5668 & Cold Market & \\
\hline May-08 & 1.3341 & 2.5040 & Cold Market & \\
\hline Jun-08 & 1.6938 & 2.4369 & Cold Market & \\
\hline Jul-08 & 1.7345 & 2.2695 & Cold Market & \\
\hline Aug-08 & 1.5998 & 2.1761 & Cold Market & \\
\hline Sep-08 & 1.3996 & 1.9855 & Cold Market & \\
\hline Oct-08 & 1.2363 & 1.7871 & Cold Market & \\
\hline Nov-08 & 1.3082 & 1.5392 & Cold Market & \\
\hline Dec-08 & 1.1968 & 1.2858 & Cold Market & \\
\hline Jan-09 & 1.2207 & 1.3232 & Cold Market & \multirow{12}{*}{ Hot Market } \\
\hline Feb-09 & 1.2034 & 1.3476 & Cold Market & \\
\hline Mar-09 & 1.2202 & 1.3485 & Cold Market & \\
\hline Apr-09 & 1.2868 & 1.3695 & Cold Market & \\
\hline May-09 & 1.5100 & 1.3842 & Hot Market & \\
\hline Jun-09 & 1.7150 & 1.3859 & Hot Market & \\
\hline Jul-09 & 1.9645 & 1.4051 & Hot Market & \\
\hline Aug-09 & 2.3279 & 1.4658 & Hot Market & \\
\hline Sep-09 & 2.1738 & 1.5303 & Hot Market & \\
\hline Oct-09 & 2.1912 & 1.6099 & Hot Market & \\
\hline Nov-09 & 2.0186 & 1.6691 & Hot Market & \\
\hline Dec-09 & 2.2656 & 1.7581 & Hot Market & \\
\hline Jan-10 & 2.3133 & 1.8492 & Hot Market & \multirow{12}{*}{ Hot Market } \\
\hline Feb-10 & 2.3344 & 1.9435 & Hot Market & \\
\hline Mar-10 & 2.0919 & 2.0161 & Hot Market & \\
\hline Apr-10 & 2.1837 & 2.0908 & Hot Market & \\
\hline May-10 & 1.8405 & 2.1184 & Cold Market & \\
\hline Jun-10 & 2.0349 & 2.1450 & Cold Market & \\
\hline Jul-10 & 2.0673 & 2.1536 & Cold Market & \\
\hline Aug-10 & 1.9119 & 2.1189 & Cold Market & \\
\hline Sep-10 & 2.4910 & 2.1454 & Hot Market & \\
\hline Oct-10 & 2.4769 & 2.1692 & Hot Market & \\
\hline Nov-10 & 2.6040 & 2.2180 & Hot Market & \\
\hline Dec-10 & 2.8376 & 2.2656 & Hot Market & \\
\hline Jan-11 & 1.9200 & 2.2328 & Cold Market & \multirow{3}{*}{ Cold Market } \\
\hline Feb-11 & 2.0090 & 2.2057 & Cold Market & \\
\hline Mar-11 & 2.0592 & 2.2030 & Cold Market & \\
\hline
\end{tabular}




\begin{tabular}{|c|c|c|c|c|}
\hline Apr-11 & 2.1628 & 2.2013 & Cold Market & \\
\hline May-11 & 2.1974 & 2.2310 & Cold Market & \\
\hline Jun-11 & 2.0844 & 2.2351 & Cold Market & \\
\hline Jul-11 & 2.2716 & 2.2521 & Hot Market & \\
\hline Aug-11 & 2.0666 & 2.2650 & Cold Market & \\
\hline Sep-11 & 1.9306 & 2.2183 & Cold Market & \\
\hline Oct-11 & 2.0324 & 2.1813 & Cold Market & \\
\hline Nov-11 & 2.0815 & 2.1377 & Cold Market & \\
\hline Dec-11 & 2.1102 & 2.0771 & Hot Market & \\
\hline Jan-12 & 2.4427 & 2.1207 & Hot Market & \multirow{12}{*}{ Cold Market } \\
\hline Feb-12 & 2.4995 & 2.1616 & Hot Market & \\
\hline Mar-12 & 2.6349 & 2.2095 & Hot Market & \\
\hline Apr-12 & 2.3156 & 2.2223 & Hot Market & \\
\hline May-12 & 2.1148 & 2.2154 & Cold Market & \\
\hline Jun-12 & 2.0536 & 2.2128 & Cold Market & \\
\hline Jul-12 & 2.0812 & 2.1970 & Cold Market & \\
\hline Aug-12 & 2.0177 & 2.1929 & Cold Market & \\
\hline Sep-12 & 2.1589 & 2.2119 & Cold Market & \\
\hline Oct-12 & 2.1690 & 2.2233 & Cold Market & \\
\hline Nov-12 & 2.1922 & 2.2325 & Cold Market & \\
\hline Dec-12 & 2.1410 & 2.2351 & Cold Market & \\
\hline Jan-13 & 2.0915 & 2.2058 & Cold Market & \multirow{12}{*}{ Cold Market } \\
\hline Feb-13 & 2.2422 & 2.1844 & Hot Market & \\
\hline Mar-13 & 2.4173 & 2.1663 & Hot Market & \\
\hline Apr-13 & 2.2649 & 2.1620 & Hot Market & \\
\hline May-13 & 2.2966 & 2.1772 & Hot Market & \\
\hline Jun-13 & 2.2396 & 2.1927 & Hot Market & \\
\hline Jul-13 & 2.1160 & 2.1956 & Cold Market & \\
\hline Aug-13 & 1.9830 & 2.1927 & Cold Market & \\
\hline Sep-13 & 2.0402 & 2.1828 & Cold Market & \\
\hline Oct-13 & 2.0761 & 2.1751 & Cold Market & \\
\hline Nov-13 & 2.2444 & 2.1794 & Hot Market & \\
\hline Dec-13 & 2.1665 & 2.1815 & Cold Market & \\
\hline
\end{tabular}

